\title{
Public policies against criminal assets in mexico: challenges and opportunities from the north border states
}

\author{
Pedro R. Torres Estrada ${ }^{1}$ (D) Juan C. Montero Bagatella ${ }^{1}$ (D) \\ Carlos Vázquez Ferrel ${ }^{1}\left[\right.$. Sylvia C. García Mariño ${ }^{1}$
}

Accepted: 29 March 2021 / Published online: 2 June 2021

(c) The Author(s) 2021

\begin{abstract}
Given its vast border with the United States, Mexico is a strategic trade and economic development region, which creates significant challenges in combating crime and violence. In recent years, Mexico's federal and state governments have focused their efforts on the development of strategies to combat and weaken the criminal structures operating in the country by using legal instruments such as seizure, abandonment, and extinction of domain. This study seeks to identify the challenges faced by the states of Baja California, Chihuahua, Coahuila, Nuevo Leon, Sonora, and Tamaulipas in their efforts to combat crime through the collection of primary and secondary data and interviews with key actors. Mexico faces major challenges in the development of public policies to fortify the legal precepts of extinction of domain, in addition to fostering institutional links with the Financial and Patrimonial Intelligence Units of Mexico's northern Border States. There are few studies about subnational efforts for asset forfeiture as a policy instrument against criminal elements in developing countries. The Mexican case presents important subnational efforts to improve security strategies that may provide guidance for other subnational governments or regions that may be facing similar challenges or are pursuing parallel initiatives.
\end{abstract}

\section{Introduction}

The Latin American region has faced an unprecedented public security crisis. Violence has soared in Mexico, much of Central America, and some countries in South America. This situation is made evident by the rise in homicides, victimizations, and restriction of freedoms. Several initiatives to combat violence and criminality have been implemented, including military and police deployment and peace and

Pedro R. Torres Estrada

pedro.torres@tec.mx

1 Tecnologico de Monterrey, School of Government and Public Transformation, Nuevo Leon, Mexico 
development programs. However, crime has continued to worsen and prison populations have soared [1].

This is the context for the present research. This study focuses on an alternative crime-fighting strategy in Mexico: tackling crime on the economic front through asset forfeiture policies at the subnational government level. These strategies constitute an effort to strengthen the government's capabilities to financially undermine criminal organizations. The research was conducted in Mexico, a country plagued by criminal organizations that control several regions, which suffers from institutional weakness, [2-5] and where violence reached record levels from 2017 to 2019 [6].The rule criminal organizations exert over different regions relies on the use of violence, that is clearly visible, but especially political corruption, that cannot be easily seen and can be confused with peace and stability [7, 8].

The link with political authorities allows criminal organizations to corrupt local, state and federal authorities, allowing criminals to exert significant influence and even control governments [9-11]. Such access, for example, facilitates the granting of permits to open businesses that provide cover for money laundering-bars, casinos, dance clubs, liquor stores, and so on. Protection of their drug trafficking routes is another benefit purchased by political financing, allowing the criminal cartels to move freely through vast territories through collusion with officials [11, 12]. One consequence has been diversification of their activities into other types of crimes, such as kidnapping and extortion $[13,14]$. This strategy has generated fear in voters, affecting democracy and electoral participation $[15,16]$, but has also allowed criminals to obtain greater territorial control and weaken public institutions [2].

Within this scenario, Mexico's subnational governments have developed different strategies to improve their institutional capabilities to fight crime while acknowledging the need for collaboration from different government levels [17], innovative measures, and cooperation within and outside subnational governments [18].

The cases presented in this paper reflect the efforts of the north border Mexican states to implement asset forfeiture as a policy measure through the legal device of "extinction of domain." This policy instrument has been applied in other countries but is new to Mexico. This policy instrument is part of a strategy that treats security as a multilevel governance issue where the federal, state, and local governments share legal responsibilities and capabilities. The national law was enacted in 2019, but state efforts had already been implemented several years before, presenting the subnational level as a space for policy innovation and experimentation. This approach makes the cases presented in this paper a resource for policymakers in different subnational governments and regions for learning from the failures and successes of the Mexican situation.

The security strategy in Mexico was designed by the National Public Security System and implemented through the federal and state governments. The states play a key role in the strategy to combat violence, but remain heavily dependent on the actions and resources of the federal government to fight criminal organizations. The states use federal armed forces [19] as well as financial institutions, such as the Intelligence Financial Unit, to address the economic aspect of criminality [20] but have not developed or improved their own police institutions [9], justice systems [21], or their intelligence financial units [22]. 
National policies to tackle the economic aspects of criminality have been instituted through recently enacted laws. In 2009, during the Felipe Calderon administration (2006-2012), the federal government enacted the first legal reforms to bolster the fight against money laundering [23]. In 2015, during the Enrique Peña administration (2012-2018), the federal government promoted the National Anti-Corruption System to promote intergovernmental cooperation to prevent, identify, prosecute, and sanction corruption and strengthen accountability for public resources [24].

The states followed the federal example and developed their own "extinction of domain" laws. However, not all states did so at the same time, understandably so given the poor results from the first set of legal reforms [25]. As noted by the prosecutor of the state of Tamaulipas in one interview, the previous legislation focused on the creation of specialized units, staff training, and collaboration among different governmental agencies, but lacked clear procedures for asset forfeiture. Thus, the states began reforming their laws, as listed in the following table:

\begin{tabular}{lll}
\hline First enactment & \multicolumn{2}{l}{ Reformed } \\
\hline Mexico City & 2008 \\
Chiapas, Nuevo Leon, San Luis Potosi, & 2009 & \\
$\quad$ Tabasco & 2010 \\
Chihuahua & 2011 & \\
Guanajuato, Hidalgo, Mexico State, Puebla & 2012 & \\
Baja California & 2013 & Nuevo Leon \\
Coahuila, Oaxaca & 2014 & San Luis Potosi \\
Baja California Sur, Campeche, Colima, & & \\
$\quad \begin{array}{l}\text { Durango, Guerrero, Michoacan, Morelos, } \\
\text { Nayarit, Queretaro, Quintana Roo, Tlaxcala, } \\
\text { Veracruz }\end{array}$ & & \\
Aguascalientes, Jalisco, Sonora, Zacatecas & 2015 & Puebla, Oaxaca \\
Sinaloa, Tamaulipas & 2016 & Chihuahua, Guanajuato, Hidalgo, Mexico State \\
& 2017 & Mexico City, Tabasco, Durango, Aguascalientes, \\
& & Sonora \\
& 2018 & Baja California, Nayarit, Queretaro \\
& 2019 & Coahuila, Yucatan \\
& 2020 & Veracruz \\
\hline
\end{tabular}

Table 1, Own elaboration based on each state laws.

The laws and reforms following 2013 can be seen as the basis for the federal and Constitutional reform of 2019, which finally considered extinction of domain as a tool for asset forfeiture. That same year, the National Law for Extinction of Domain was enacted as a tool against organized crime, kidnapping, petroleum trafficking, drug trafficking, human trafficking, public corruption, car theft, money laundering and extortion.

The legal instruments considered in the extinction of domain legislation have been implemented, particularly in states such as Chihuahua, Coahuila, Nuevo Leon, Sonora and Tamaulipas, where former governors face charges of political corruption and unexplained wealth. These efforts by the states to tackle the economic aspect of criminality are very recent and should be considered as an ongoing regional effort 


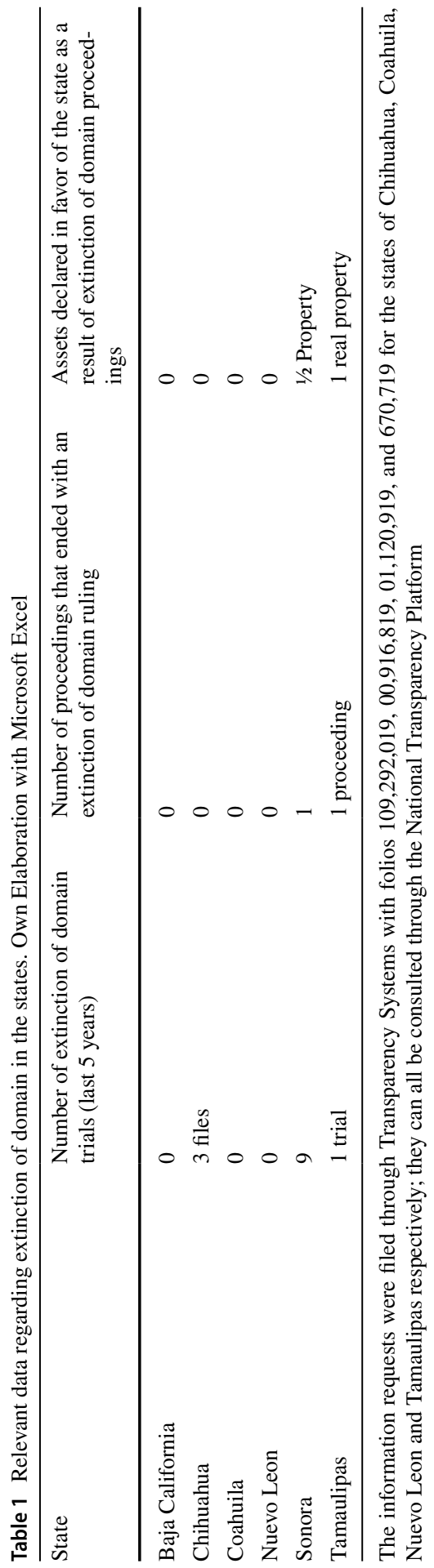


across Mexico. However, this study's relevance rests on the analysis of the states and regions as spaces for innovative policymaking, wherein observing and comparing policy instruments, failures, results, and challenges with other regions and subnational governments [17] can help provide guidance for stakeholders.

The purpose of this paper is to analyze the efforts made by the north border Mexican States and against criminal assets, especially through asset forfeiture. This instrument is framed within the legal figures of "Transactions with Illicitly Obtained Resources" and "extinction of domain." The policy measures implemented by the north border Mexican states against criminal assets are compared with similar initiatives taken in other countries, especially with civil and criminal asset forfeiture. These policies involve the participation of multiple agents at the state level, such as offices dealing with taxation and finances and state prosecutors are autonomous from the governor's office, as well as different federal entities for specific procedures. The paper then examines the specific bodies created by the states to carry out these policies, identifying their early results and existing problems and challenges.

The analysis of these cases demonstrates the capacity of subnational governments to create their own policies for tackling the economic aspect of criminal operations-specifically criminal assets. This research contributes to identifying how regional and subnational governments improve different public policies across the country, comparing their specific results with other subnational governments and regions. Finally, the study also reveals the complexity of developing and implementing asset forfeiture in a context where different actors participate in different jurisdictions, requiring multilevel governance to be enforced as a policy instrument against criminal assets.

\section{Methodology}

This research is based on case studies of the north border Mexican states, stressing the legal particularities of "extinction of domain" as a policy instrument to fight the economic side of criminality.

The cases were selected by the following criteria. First, in December 2018 the research team conducted a workshop and research panel with Mexican and American academic experts and federal and state practitioners, identifying and discussing relevant national and subnational issues with the assessment of the federal Financial Intelligence Unit. Three key points were raised in this first exercise: (1) the identification of the heterogeneity development of the specialized state units for asset forfeiture, called in some states Financial Intelligence Units (UIF) or Patrimonial and Financial Intelligence Units (UIPE); (2) the case of Tamaulipas was considered a good practice because of the results against former governors and important criminals; (3) there was not good communication between the state units and the federal authorities to support state investigations. This first meeting provided insight into defining the pertinent cases for study, such as the crucial development of the financial intelligence units in the northern states and the processes against former governors and important criminals, as well as the relationship between the state and federal financial units. 
Second, in May 2019, the research team attended and participated in the National Meeting of Patrimonial and Economical Units, conducting a questionnaire to all representatives of the state units. ${ }^{1}$ From this exercise, the research team discovered that, save for Baja California, Guanajuato, Hidalgo, Nayarit, Oaxaca, San Luis Potosi, and Yucatán, almost all states had developed specialized units. However, there are several differences in the government sector where the unit is located and its legal capabilities. From these two exercises, the team identified the states of Chihuahua, Coahuila, Nuevo Leon, and Tamaulipas as four relevant cases based on the stages of development of their units and their early results. For the purpose of maintaining the study's geographic integration and also taking into account the shared economy, culture, and history with the United States of America, it was decided to include the states of Sonora and Baja California.

Given that the legal initiatives by the states are quite recent, there is almost no information regarding this topic. Consequently, semi-structured personal interviews were conducted with attorney-generals, prosecutors, heads of the economic intelligence units in the aforementioned states, the head of the Federal Financial Intelligence Unit, and the Deputy Director for the Prevention of Transactions with Illicit Proceeds Office of the National Banking Commission (CNBV). Document research and information requests in the institutional transparency systems were also done.

This research arises from the following considerations. First, violence in Mexico is strongly related with criminal organizations [4, 26], especially Drug Trafficking Organizations (DTOs) [27]. The second consideration is that most criminal organizations seek profits from trafficking illegal goods, so they require complex logistical chains that link the production of goods with the markets where they are sold [7, 28]. They also have to distribute and deliver their gains within the organizations and to their leaders, disguising the unlawful origin of said resources to make them appear legal-i.e., money laundering [29]. Third, criminal organizations in Mexico cannot be understood only as nationwide organizations or cartels. They are also the union of several organizations and gangs that specialize in certain activities or control specific territories [30, 31]. Consequently, a strategy against the criminal organizations responsible for most of the violence in Mexico requires a complex response, based not only on the use of force, but also directed against the assets of crime [32]. It must also be understood that the complex union of organizations allows for the states and even local governments to participate in this strategy by identifying and neutralizing organizations that operate within their territories and jurisdictions, through force and by attacking the assets of crime.

This study focuses on the institutional capabilities of Mexican state governments against criminal assets. The main policy instruments for the states to utilize in the strategy against criminal assets are those used to identify and sanction Transactions with Illicitly Obtained Resources (ORPI), especially through extinction of domain which can be understood as an asset forfeiture mechanism. These instruments, according to the relevant legislation, focus on four high-impact crimes in Mexico ${ }^{2}$ : human trafficking, kidnapping, car theft, and drug trafficking.

\footnotetext{
1 The states of Baja California Sur, Campeche, Durango, Jalisco, Morelos, Sinaloa and Tlaxcala did not attend the meeting and neither did answer the questionnaire.

2 The Public Security National System, defines "high impact crimes" as a those that due to their degree of impact cause greater damage to citizens [70].
} 
The study focuses on Mexico's northern Border States: Baja California, Sonora, Chihuahua, Coahuila, Nuevo Leon, and Tamaulipas, all strongly linked to the United States of America through their economy, history, migration, and culture [33]. This linkage is derived from a transport and communications network that incorporates the four states into an interdependent economic dynamic. The region has common characteristics such as dynamism and a concentration of added-value industrial zones [34]. With $17.8 \%$ of the whole Mexican population [35], the region contributes $19.74 \%$ of the national GDP and represents one of the highest GDP per capita rates in Mexico [36], along with a low poverty rate [37]. Mexican exports to the United States represent $76.49 \%$ of all Mexican exports, and $61 \%$ of exports to the USA are sent by land through these states. In terms of criminal activity, car thefts have the highest incidence, followed by drug dealing, homicide, kidnapping, and human trafficking, as shown in Fig. 1.

The data show that the north region has had high crime rates for the past five years. This is highly pertinent since this region represents one of Mexico's most important economic zones, given its industrial role and geographic situation as a border with the United States.

The following section of the article describes and analyzes the legal instruments to tackle the assets of crime in these four states. Next, based on the analysis and interviews conducted with key players from the federal government, a policy proposal is presented with the objective of promoting policy learning derived from the early efforts by the four states.

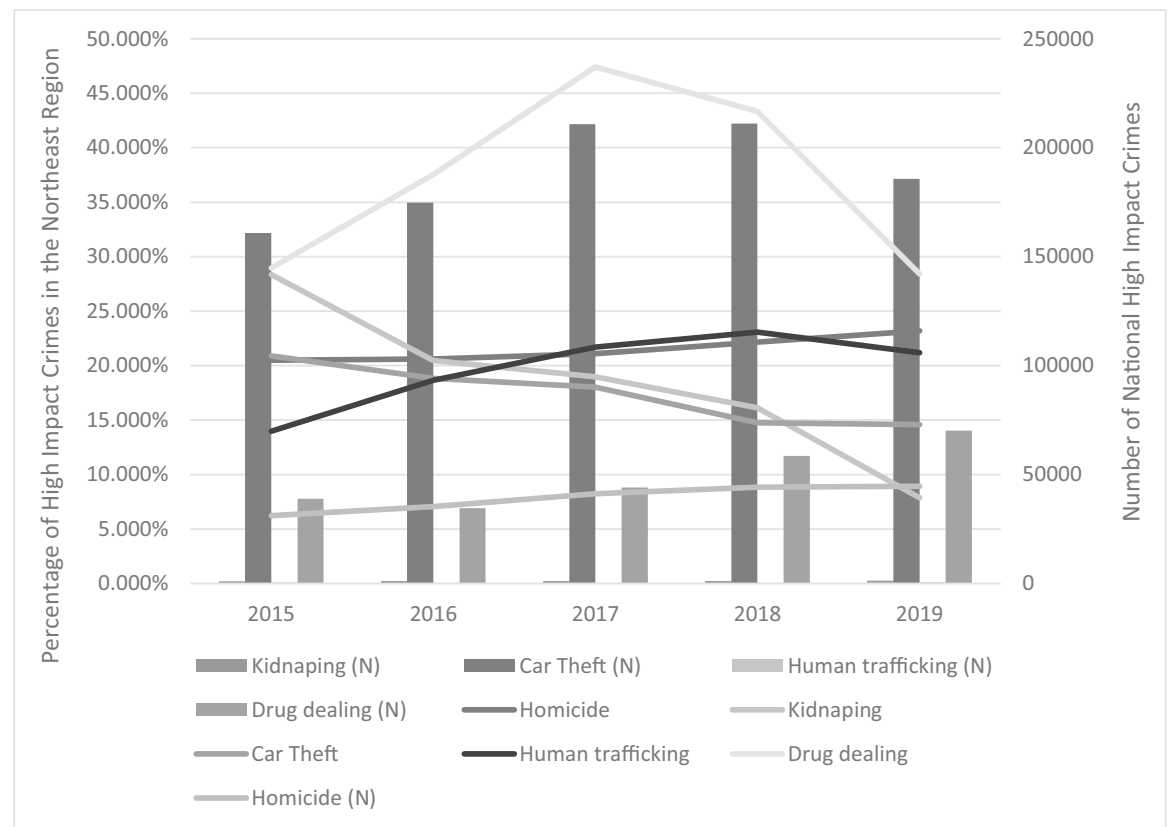

Fig. 1 High impact crimes in Mexico's northeastern region and at national level. [38] Own Elaboration with Microsoft Excel 


\section{Policy instruments against criminal assets}

As previously noted, most criminal organizations, regardless of their size, aim to extract economic benefits from their illegal activities [39]. The impact of criminal organizations, especially those involved in drug trafficking (DTOs), has led to these groups being defined as a national security risk and aroused the necessity of the federal government instituting measures to combat them. To achieve this, a regulatory framework has been developed for police institutions and the armed forces to combat criminal organizations. Also, the Ministry of Finance and Public Credit (SHCP) and the Attorney General's Office (FGR) have been provided with tools to take on the financial side of their operations. The Rules of the Federal Law for the Prevention and Identification of Transactions with Illicit Proceeds (LFPIORPI) are geared to destroy money laundering sources, re-classifies tax evasion to identify unexplained wealth, and facilitates collaboration with criminal or corruption investigations and the National Law on Extinction of Domain (LNED) to directly attack the assets of crime. The states share these instruments through their laws on fiscal evasion, extinction of domain, and the prosecution of transactions with illicit proceeds [25], but only a few states have put these laws into practice.

One of the most common instruments implemented against the assets of crime and money laundering is asset forfeiture ${ }^{3}[40,41]$. The legal concept developed in Mexico is "extinction of domain," which is very similar to "extinction of ownership" as developed in countries like Spain, and "civil asset forfeiture," as developed in countries like Ireland, South Africa, and the United States. These are all legal means for transferring property derived from criminal acts to the state [42] without a conviction, arrest, or charges against a specific person [43]. However, in Mexico, federal courts have ruled that the legal application of extinction of domain requires the existence of an ongoing legal process for it to proceed in court. [44].

There are two common types of forfeiture, civil and criminal. Civil asset's forfeiture (in rem) only requires that there is probable cause that the property is tainted, without criminally convicting the owner [40, 45]. Regarding criminal forfeiture (in personam), the government confiscates property as part of a criminal ruling [46]. Countries like the United Kingdom, Australia, and the United States have a long history of implementing assets forfeiture to combat organized crime [47], and countries like Ireland and Indonesia also target unexplained wealth [48, 49].

In Mexico, the legal instrument of extinction of domain was incorporated into the constitutional reform of Article 22, as well as to the Federal Law on Extinction of Domain enacted in May, 2009 with the aim of hitting crime "where it hurts the most-their money [50]. However, as mentioned in interviews with the prosecutors in Nuevo Leon and Tamaulipas, this law was very bureaucratic and not include building specialized units and training staff for analyzing financial information and using the proceeds as funding for prosecuting crime. As a consequence, the states began reforming their laws and, in 2019, the National Law on Extinction of Domain was approved with the objective of encompassing the actions of all the states.

\footnotetext{
${ }^{3}$ Some countries in the European Union have a harmonization process to classify the crime of money laundering [69]. The term money laundering has been used by the Organization of American States since 1991 [71].
} 
Extinction of domain has been implemented as a federal tool against DTOs [23, 51,52 ], but has had few successes [65]. It is a legal hybrid between civil assets forfeiture and criminal assets forfeiture, because it has been interpreted by the Federal Courts as a civil procedure against an asset involved in a crime [53], but requires a criminal proceeding against the owner. However, for the extinction of domain to proceed, even when a legal proceeding against the owner is required, it is only necessary to prove that the asset was linked to the crime. There is no onus to prove the owner's guilt or obtain a criminal sentence. Furthermore, the burden of proof rests on the owner to demonstrate the legal status or "innocence" of the asset, as in the case of Spain with the figure of "extinction of ownership" [54].

The complexity of the Extinction of Domain figure in Mexico remains in the incorporation of the criminal, civil, and administrative laws [52]. These fields refer to the establishment of property rights on certain assets before a judicial authority for such rights to be allocated to the State without compensation to the affected party. Several federal courts have ruled on this instrument identifying it as a civil rather than a criminal matter [44, 55] and legally distinct from expropriation and seizure [56]. Besides, the public ministry or the prosecutor's office is responsible for proving that the assets have been the instrument, object, or product of an illicit activity [57]. Accordingly, it is the persecutor's responsibility to investigate extinction of domain, but this requires the collaboration of the criminal, civil and administrative areas.

In the United States, assets forfeiture has been used as a law enforcement policy instrument designed to stymie the gains and profits of crime [47]. It has especially incentivized anti-drug policies [41, 43], but some studies have shown that this measure has not had the expected outcomes because it created incentives to forfeit property and money, but not prosecute the actual dealers [58] or the elements that make drugs profitable [59-61]. ${ }^{4}$ All states have their own forfeiture laws due to equitable sharing programs with the federal government [62], incentivizing state seizures and forfeitures to a level where the revenues from forfeitures often exceed the budget of the law enforcement agencies [42]. This has fostered police abuse, leading to constitutional disputes and several state law reforms across the country [63].

After the enactment of the federal law in Mexico, states also enacted their own laws on extinction of domain; however, these laws have not been especially effective [64] and have been viewed as a failure [25] due to the small number of cases that have been filed and won [65].

Given the precepts of the Law on Extinction of Domain (LFED) in the north Border States, it follows that the extinction of domain precept is admissible in the commission of kidnapping, human trafficking, car theft and drug dealing, ${ }^{5}$ regarding the following assets:

\footnotetext{
4 This is an important issue to consider for the Mexican case because even when illicit drug trafficking is a federal crime, the states have legal attributions on illicit drug distribution [72], so asset forfeiture could become an incentive to target consumers instead of major distributors.

5 Article 7 of Chihuahua's Extinction of Domain Law; Article 20, Section II of the Political Constitution of the Free and Sovereign State of Nuevo Leon and Article 10, Clause 1 of Tamaulipas's Extinction of Domain Law. Additionally, Coahuila added the crime of Criminal Facilitation, Article 9, Section V of the Extinction of Domain Law.
} 
I Assets that have been an instrument, object or product of a crime,

II Assets that have been used to hide or mix assets product of a crime;

III Assets used by a third party to commit a crime, provided that the owner is aware of said purpose;

IV Assets registered under the name of a third party, where there's sufficient evidence to prove that they are the proceeds of a crime and the party accused of committing the crime appears as the owner of said assets. ${ }^{6}$

As previously noted, in the United States assets forfeiture has been subject to abuse in some states because law enforcement agencies receive most of the gains from these forfeitures. In the case of Mexico, however, the gains are distributed between different agencies and the enforcement agencies only receive a portion. ${ }^{7}$ Therefore, state law enforcement agencies in Mexico lack an economic incentive to enforce assets forfeiture. However, one relevant issue on the analyzed states is that, as mentioned in an interview by Nuevo Leon's State Prosecutor, American states provide information to the Mexican Federal and State governments to improve both Mexican and American operations against criminal organizations.

Extinction of domain is a complex legal device that creates significant collaboration problems between the different agencies. For example, prosecutors, public ministries, and judges are all involved in the preparation, filing, information-gathering, and resolution of legal proceedings. Similarly, government agencies that oversee the state's public finances need to collaborate among themselves. Finally, there is a need for intergovernmental collaboration between the prosecutor's offices of the federal entities with both the Attorney General's Office (FGR) and the Financial Intelligence Unit of the SHCP, in addition to working together with state and federal judges. This process is not functional because, as the chairwoman of the National Banking Commission responsible for prevention of operation with resources from illicit proceeds explained, the states have not developed the resources to analyze financial information, lack technology and human resources, and spend years analyzing information provided by the federal authorities.

The complexity of the extinction of domain proceeding reduces the chances of it being employed as part of a government strategy. In this regard, the public safety strategies of the states were reviewed for the period starting from the enactment of the extinction of domain acts mentioned in Chart $1 .{ }^{8}$ The governor's annual reports were also examined for references or results related to extinction of domain as a policy instrument. Information requests were also sent to the judicial powers and public prosecutors' offices of the referred states to obtain data on the number of extinction

\footnotetext{
${ }^{6}$ Article 8 of Chihuahua's Extinction of Domain Act, Article 10 of Coahuila's Extinction of Domain Act, Article 8 of Nuevo Leon's Extinction of Domain Act and Article 10 of Tamaulipas's Extinction of Domain Act.

7 According to the National Extinction of Domain Act, gains from forfeited assets have to be equally distributed among the judicial power, the General Attorney's Office and a special victims' fund. Every state defines in its own laws the specific rules to distribute the gains from forfeited assets.

${ }^{8}$ The research first considered government's plans to identify if the current governor considered extinction of domain as a policy instrument for the security or anti-corruption strategies. This process considered the administrations 2013-2019 and 2019-2021 for Baja California, 2010-2016 and 2016-2021 for Chihuahua, 2015-2021 for Sonora, 2011-2017 and 2017-2023 for Coahuila, 2009-2015 and 2015-2021 for Nuevo Leon, 2011-2016 and 2016-2022 for Tamaulipas.
} 
of domain proceedings filed and resolved. Finally, the prosecutors in Nuevo Leon and Tamaulipas responsible for said matters were interviewed to get their experience and views on the government's capacities to combat the assets of crime.

According to the development plans and annual reports of these federal entities, combating illegal transactions or tackling the assets of crime has not been part of the security strategy. The issue is not mentioned, no objectives or proceedings are proposed, and no results are reported. In the government's plans, none of the governors' reports mentioned combating transactions with illicit proceeds, extinction of domain, or any other measures aimed at criminal assets as part of their security or anti-corruption strategies. Every state included different strategies to strengthen its police institutions, intelligence capabilities, and infrastructure, but there is no mention of combating the finances of criminal organizations or implementing extinction of domain as a public policy instrument. Along the same lines, governors' annual reports do not emphasize dealing with the economic aspects of crime, although they do refer to extinction of domain as part of their legislative agenda. The only references related to the implementation of extinction of domain were found in the annual reports of Chihuahua, where the governor announced the first two successful procedures by the government [66], and Sonora in 2018, where the governor noted the creation of a specialized unit to implement asset forfeiture and, again in 2019, revealed that this unit was prosecuting 78 different cases, especially targeting drug trafficking, and had won one case [67]. This is an important lacuna because it shows that attacking criminal assets is not part of the public security strategy in the states and such initiatives therefore will not have resources and support from the state government.

The laws and reforms in the field of extinction of domain have not led to specific proceedings or results, demonstrating that the reforms promoted in the states have sought only to harmonize state and federal regulations but not actually use them to seize criminal assets or halt related transactions. To this end, information requirements were submitted to the judicial powers and the states' prosecutors' offices, regarding the number of extinctions of domain proceedings filed and resolved. ${ }^{9}$ The response revealed that the judicial authorities of the state of Chihuahua received and resolved eight extinction of domain proceedings, ruling in favor of the attorney general in only two cases; however, no file numbers, dates, or amounts involved were included. The chairwoman of the National Banking Commission, which is responsible for preventing operations with resources from illicit proceeds, considered Chihuahua had one of better state records, having developed a specialized unit with technological and human capabilities for analyzing financial information provided by the federal government. In the states of Coahuila and Nuevo Leon, by contrast, the prosecutor's office and the judicial powers had not filed or resolved any extinction of domain case. In Tamaulipas, the public prosecutor's office reported that it filed and obtained a favorable extinction of domain resolution for a property valued at 800,000 Mexican pesos.

The lack of criminal proceedings in the field of extinction of domain presumes the existence of other factors that may influence this failure. To explore this issue,

\footnotetext{
9 The transparency requests were presented with folios 00,986,920 for the case of Baja California, 076,102,019 for Chihuahua; 00,677,819 for Coahuila; 00,828,119 and 00,828,019 for Nuevo Leon; and 01,045,120 for Sonora, and 00,457,019 and 00,456,919 for Tamaulipas. They can all be consulted through the National Transparency Platform.
} 
the prosecutors responsible for combating the assets of crime in the states of Nuevo Leon and Tamaulipas were interviewed. They noted that the entities specializing in combating the assets of crime were just two years in existence and did not have expert personnel in this area. They also noted the lack of collaboration within the government's structures, with no substantive and ongoing communication between the sectors responsible for public safety or with the treasury, which prevents them from filing proceedings based on the identification of suspicious transactions. Finally, the prosecutors acknowledged that they lack specialized staff capable of simultaneously addressing the criminal, fiscal, administrative, and civil rights surrounding crime assets seizure. Moreover, there are no judges who specialize in this area so, even if proceedings are filed, the outcomes are uncertain.

The interviewees also pointed out that the procedure to file an extinction of domain case is not straightforward. Uncertainty exists about how files should be integrated, causing prosecutors to rely on other legal precepts. ${ }^{10}$ This works well for property obtained from special transactions, particularly vehicles, weapons, and cash, but are ineffectual in cases involving houses, bank accounts, and other assets associated with DTOs.

When addressing the issue of intra-governmental collaboration, prosecutors acknowledged the support of the treasuries or units responsible for the treasury in their states. However, they admitted that interaction with the Financial Intelligence Unit of the Finance Ministry and other federal entities were problematic. In the same vein, the chairwoman of the National Banking Commission noted that collaboration with the states is weak because of the lack of technological and human resources to conduct financial analysis and apply the information to criminal procedures. Consequently, the states and the federal government do not rely on each other for financial investigations and do not collaborate. The chairs of both the Financial Intelligence Unit and the National Banking Commission admitted that this is partly because the states have to request banking and financial information. Prosecutors responsible for specific cases do not have the authority to freeze bank accounts but must apply to the federal offices, making the process slow and bureaucratic. Also, state prosecutors are typically rotated, which makes it virtually impossible to follow up on cases. Only Chihuahua had built a strong relationship between their prosecutor's office and the National Banking Commission and the Financial Intelligence Unit.

Finally, prosecutors noted the lack of incentives to file extinction of domain cases. Before the prosecutors' offices became autonomous, the resources obtained from criminal investigations were integrated into victims' funds or used for compensation but, under the new dispensation, it is unclear how the resources are managed. As a result, there are no incentives for prosecutors to specialize on extinction of domain, file these appeals, and integrate the files.

In sum, combating Transactions with Illicit Proceeds and extinction of domain are not part of the government's strategies, prosecutors' offices have no incentives to file extinction of domain cases and the required human resources and intergovernmental collaboration are lacking. However, it should be acknowledged that, within

\footnotetext{
${ }^{10}$ When an asset is declared as abandoned, an administrative proceeding is executed for the state to assume its control, safeguarding the right of the possible owner to claim it, but given that the asset is associated with a criminal act, it is generally not claimed and it is transferred to the State's control.
} 
the past few years, the prosecutors' offices have started developing specialized structures to pursue these legal strategies.

The following section presents a proposal to reinforce the policy against criminal assets in Mexico's states. The recommendations are informed by the challenges faced by the units of the states under study and interviews of state prosecutors, the head of the Intelligence Financial Unit, and the chairwoman of the National Banking Commission.

\section{Developing public policies to combat assets of crime in subnational governments}

Criminal policy is ideally shaped by cogent reasons for prioritizing certain types of crime over others and applying limited human and technical resources accordingly. States must initially evaluate which crimes they have to combat in the context of their particular situation. Thus, each state must determine the priority they must give to dismantling the financial structures of criminal organizations as part of their policy on Transactions with Illicit Proceeds and extinction of domain of criminal assets [68].

Some subnational governments will be more interested in investigating cases of political corruption (which usually have a greater media impact) and, as a strategic move, other states will start with high-impact crimes that have more dire effects on their communities. The Mexican case, with the assessment of the federal agencies and the cases studied, emphasized the importance of targeting Transactions with Illicit Proceeds.

The federal and subnational experience in Mexico underlines the importance of developing specialized units within the responsible dependencies for enforcing asset forfeiture. Initially, states will be required to review the information they have at their disposal. The construction of these databases is often challenging. Databases provide the raw material required for intelligence analysis. According to the chairwoman of the National Banking Commission, the relevant state units do not have the resources or personnel needed to analyze the information provided by her office. This highlights the need to train prosecutors and keep them in their positions, given that typical rotation of personnel adds to the difficulty of building strong relations between the states and the Commission. As previously mentioned, asset forfeiture requires collaboration between different financial, civil and criminal departments, which sharing databases crucial. The challenges lies in creating data-sharing agreements with other units and agencies to be able to use intelligence products as evidence in judicial proceedings, given that, if there is no existing agreement to exchange information, the findings will not be admissible in court.

Similarly, tools designed to store and cross-reference information require training for analysts. The prosecutors of Nuevo Leon and Tamaulipas both noted the lack of support from decision-makers to strengthen the units. The chairwoman of the CNB also admitted that they could not build strong relations with the states because of constant changes in the unit's staff, making it almost impossible to follow the investigation process for specific cases. For this reason, recruitment is an important part of the consolidation process of this Public Policy, since analysts are the ones who develop the final product that will be provided to prosecutors for the judicial 
process. In contrast, the chairwoman of the CNB noted that the lack of human and technological resources in the states weakened collaboration and trust with federal agencies. In this sense, the challenge is to break the existing resistance and mistrust about sharing information between agencies and governments, especially regarding financial, patrimonial, and economic issues.

There is an ongoing debate about where the specialized units should be locatedwhether in the finance ministries, the autonomous public prosecutors' offices, or the law enforcement units. There is no set model in Mexico, neither in the federal or subnational governments. However, from the interviews with the Intelligence Financial Unit and the cases studied, the most effective case-building capacity is found in those units integrated to the prosecutors' offices in charge of prosecuting what they identify as crimes, or those derived from complaints remanded by finance or municipal units.

Prosecutors responsible for cases related to ORPIs will have to specialize in this type of crime, hence the suggestion that the same prosecutor should be responsible for the investigation files. Changing prosecutors exacerbated the following problems: deficient case follow-up; weakness in the judicial processes; corruption; and failure of the public policy. Additionally, prosecutors are not well versed in the legal precept of Transactions with Illicit Proceeds and Extinction of Domain and judges do not have the required knowledge to interpret the intelligence products to attack the assets' structures because they do not have specialized training. The research and interviews revealed that very few cases are reviewed by judges. This becomes a vicious cycle characterized by the judge's lack of training regarding Transactions with Illicit Proceeds, given the low or no referral of cases of this type.

The usefulness of the intelligence products for decision-making is crucial to legitimize the unit. Ultimately, units become service suppliers for diverse areas within the prosecutors' offices and finance ministries. Their legitimacy and strength within the institutional framework will be determined by their usefulness to the actors responsible for decision-making or integrating judicial files.

The ultimate aim is to generate intelligence products that strengthen investigation files, with the aim of increasing the likelihood of their prosecution and getting judicial decisions that undermine the finances of criminal organizations. This type of institution must work hand-in-hand with the prosecutors responsible for bringing the cases before the judges, so the prosecutor's affiliation with the working model will be decisive. In this regard, the challenge is not only to create units and train prosecutors, but also to train and guide judges. It should be noted that the National Extinction of Domain Law required the Federal Judiciary Council to create courts dedicated to extinction of domain cases within six months after enactment. ${ }^{11}$ This situation must be taken into consideration by the states under study.

Regarding the issue of increasing prosecutions and convictions, it is a good practice to monitor the proceedings from the initial investigation to the final ruling to identify good and bad practice, strengthen human resources' training, and

${ }^{11}$ Refer to article 9 of the Decree's transitional that gives effect to the National Extinction of Domain Act. 
generate proceedings protocols that can be updated with new legal and operational developments.

The high expectations for the specialized units often elide the complexities involved for successful prosecutions or even case-building. Interviews conducted with state prosecutors and representatives from the federal government revealed that, when a unit of this type is formed, results are expected within a short period, which in turn stymies thorough training. One of the most important challenges of the states' prosecutors will be to increase the court caseload and conviction rates of Transactions with Illicit Proceeds cases. Insufficient cases were identified in the states under study to statistically perform this exercise on a representative basis since they remain confidential due to ongoing legal processes. In the Mexican legal process, the prosecutors first prepare the case, then present it to a judge who rules on suitability for trial. In consequence, not all cases even reach the courts and the number of trials does not reflect the work done by prosecutors. Moreover, only the number of trials is public, but the number of cases being prosecuted are not. At present, there are very few registered extinctions of domain trials or rulings in the states under study. ${ }^{12}$

Taking the above into consideration, it is necessary to rethink the public policy strategies being used to attack criminal financial structures. However, the purpose of this study is to identify the early work, challenges, and opportunities for these efforts to be strengthened, promoting policy learning, and making clear their importance toward contributing to the strategy against criminality. ${ }^{13}$

\section{Conclusions}

Countries like Mexico confront the most worrying challenge for security because of organized crime. Through violence and corruption, crime has gained control over territories, undermined institutions, and even threatened democracy [9, 15]. The common strategy has been to fight crime through the police institutions and armed forces, but minimal effort has been made to tackle the financial side of criminality.

In this vein, several countries have developed asset forfeiture as a policy instrument against criminal assets and today are discussing the aim of this instrument because in some cases it may allow abusive powers from the police [61]. However, in Mexico this instrument has been recently enacted under the legal figure of

\footnotetext{
12 The absence of state cases contrasts with the amount of federal cases. In the federal level, since the enactment of the Extinction of Domain Law promoted several cases but, according to the interviews with the Head Chair of the Financial Intelligence Unit, this legal instrument wasn't considered as an important policy instrument for the public security strategy until recent years under the current administration of President Andrés Manuel López Obrador.

13 The absence of state cases contrasts with the amount of federal cases. In the federal level, since the enactment of the Extinction of Domain Law promoted several cases but, according to the interviews with the Head Chair of the Financial Intelligence Unit, this legal instrument wasn't considered as an important policy instrument for the public security strategy until recent years under the current administration of President Andrés Manuel López Obrador.
} 
"extinction of domain". The first try to develop "extinction of domain" as a policy instrument for asset forfeiture was in 2009 but its complexity did not allow it to be enforced had to be reformed. Nowadays, under the reforms almost all states in Mexico have developed specialized units to prosecute crime and enforce asset forfeiture as an instrument against the assets of crime.

This paper identified the existing institutional weaknesses in the northern states of Mexico in terms of asset forfeiture, making it an attractive area to launder money from drug trafficking and other criminal activities. This is a very worrisome issue, given the volume of money and commercial transactions carried out in this region. However the states face several challenges addressed in international experiences such as collaboration with different agencies, from each state, across states and with the federal government $[60,61,69]$.

The institutional weakness of Mexican states has been used by organized crime to control several regions across the country. However, asset forfeiture is a policy instrument which may improve the strategy against crime and violence, but its enforcement also requires collaboration across different agencies and developing specialized units to carry on with the investigations to build the cases and take them to trial. These units require their own legal framework, technology, but mainly need trained staff who can analyze information, collaborate with different agencies of different governments, and generate the required materials to build a case and take it to trial. As mentioned in the interviews, collaboration and trust is weak because the specialized units are very recent, do not have support from prosecutors and governors. However, in opposite cases, where these units have support, they professionalize their staff and improve on their capabilities, conducting strong investigations against criminals and corrupt politicians as shown for the cases of Sonora and Tamaulipas.

In recent years, the federal and state governments have created intelligence units to attack crime assets through the legal precept of extinction of domain. Although a powerful legal tool, this legislation has not been effectively utilized and requires administrative strengthening by improving intra- and inter-institutional communication and collaboration between the agencies, and the training of judges, prosecutors, and other actors in legal precepts to attack the assets of criminal organizations and procedures. It is also vital for these units to link with decision-makers to include asset forfeiture as a policy instrument to attack the financial gains of criminality [59].

The Mexican border with the United States is a geostrategic region, decisive for understanding drug trafficking, the exchange of money, and smuggling of weapons [20]. In the last ten years, the region experiences a large part of the violence that Mexico has experienced. Organized crime even control some territories, influence and have even captured local governments [9, 15]. However, local and federal governments are only recently considering changes in the approach to address the issues by enacting and reforming their extinction of domain laws to carry out asset forfeiture and have begun to strengthen their institutions to deal with money laundering. These are ongoing processes that may contribute to improve similar efforts in other regions of the world, with similar or lower risk characteristics [69]. 
Acknowledging the fact that crime, and specially organized crime is an important risk for several countries, the subnational Mexican experience brings lessons to improve the efforts against the economic side of criminality [20].

Finally, the interviews with key actors and the literature review allow us to identify that it is necessary for the states of the studied region establish as a priority in their government plans the fight against money laundering, the implementation of strategies aimed at controlling this problem and the effective use of the figure of asset forfeiture. On the other hand, it is recommended that state governments strengthen the legal framework for the operation of their intelligence units, emphasizing their functions, obligations, scope, and collaboration with other actors (judges, analysts, public ministries, etc.). It is recommended to give priority to topics such as: training of human resources in the legal figure of asset forfeiture, structuring of their databases and monitoring of cases involving the figure of asset forfeiture in the states.

It is important to continue studying Mexico's northern border region and all subnational experience because the phenomenon of assets' forfeiture has an impact in both countries on issues such as security and regional growth. It is necessary to conduct more studies to promote policy learning about the states' capabilities to attack criminal assets in Mexico and contribute to the public security strategy.

This article has presented the results of research conducted in Mexico, showing the efforts of subnational governments to attack the financial side of criminal organizations. Many countries face similar challenges, but this case raises the importance of subnational governments and their role in dealing with complex issues like organized crime.

Funding Not mentioned for not making any reference to authorship.

Data availability Data available on request from the authors.

\section{Declarations}

Conflicts of interest The author(s) did not have any conflict of interest during the research and the elaboration of this article.

Open Access This article is licensed under a Creative Commons Attribution 4.0 International License, which permits use, sharing, adaptation, distribution and reproduction in any medium or format, as long as you give appropriate credit to the original author(s) and the source, provide a link to the Creative Commons licence, and indicate if changes were made. The images or other third party material in this article are included in the article's Creative Commons licence, unless indicated otherwise in a credit line to the material. If material is not included in the article's Creative Commons licence and your intended use is not permitted by statutory regulation or exceeds the permitted use, you will need to obtain permission directly from the copyright holder. To view a copy of this licence, visit http://creativecommons.org/licen ses/by/4.0/.

\section{References}

1. Muggah, R., \& Aguirre Tobón, K. (2018). Citizen security in Latin America: Facts and Figures. Strategic paper 33, Igarapé Institute. A think and do tank. Obtenido de https://igarape.org.br/en/citiz en-security-in-latin-america-facts-and-figures/ 
2. Aguirre, J., \& Herrera, H. A. (2013). Institutional weakness and organized crime in Mexico: The case of Michoacán. Trends in Organized Crime, 16(2), 221-238. https://doi.org/10.1007/ s12117-013-9197-1.

3. Chinchilla, F. A. (2018). A hard-to- escape situation informal pacts, kingpin strategies, and collective violence in Mexico. Crime, Law and Social Change, 69(4), 533-552. https://doi.org/10.1007/ s10611-017-9763-6.

4. Fuerte, M. P., Lujan, E. P., \& Ponce, R. C. (2019). Organized crime, violence, and territorial dispute in Mexico (2007-2011). Trends in Organized Crime, 22(2), 188-209. https://doi.org/10.1007/ s12117-018-9341-z.

5. Williams, P. (2009). Illicit markets, weak states and violence: Iraq and Mexico. Crime, Law and Social Change, 52(3), 323-336. https://doi.org/10.1007/s10611-009-9194-0.

6. Calderón, L., Heinle, K., Rodríguez, O., \& Shirk, D. (2019). Organized crime and violence in México. Analysis Through 2018. University of San Diego, Department of Political Science \& International Relations. San Diego: Justice in Mexico. Obtenido de https://justiceinmexico.org/wp-content/ uploads/2019/04/Organized-Crime-and-Violence-in-Mexico-2019.pdf

7. Bailey, J., \& Godson, R. (2001). Organized crime \& democratic gobernability: Mexico and the U.S.-Mexican borderlands. Pittsburg: University of Pittsburg Press. https://doi.org/10.2307/j.ctt9q $\mathrm{h} 7 \mathrm{~d} 4$

8. Fuerte, M. P., Pérez, E., \& Cordova, R. (2019). Organized crime, violence, and territorial dispute in Mexico (2007-2011). Trends in Organized Crime, 22, 188-209.

9. Calderón, F. (2020). Decisionesdifíciles. . México: Penguin Random House.

10. Morris, S. (2013). Drug trafficking, corruption and violence in Mexico: mapping the linkages. Trends in Organized Crime, 16, 195-220. https://doi.org/10.1007/s12117-013-9191-7.

11. Trejo, G., \& Ley, S. (2018). Why Did Drug Cartels Go to War in Mexico? Subnational Party Alternation, the Breakdown of Criminal Protection, and the Onset of Large-Scale Violence. Comparative Political Studies, 51(07), 900-937.

12. Dulin, A. (2019). Mexican cartel negotiative interactions with the state. Trends in Organized Crime, 22, 2010-2030. https://doi.org/10.1007/s12117-017-9327-2.

13. Albarracín, J. (2018). Criminalized electoral politics in Brazilian Urban peripheries. Crime, Law and Social Change, 69(4), 553-575. https://doi.org/10.1007/s10611-017-9761-8.

14. Trejo, G., \& Ley, S. (2019). High-profile criminal violence: Why drug cartels murder government officials and party candidates in Mexico. British Journal of Political Science, 1-27.https://doi.org/ $10.1017 /$ S0007123418000637

15. Ley, S. (2017). To vote or not vote: How criminal violence shapes electoral participation. Journal of Conflict Resolution. https://doi.org/10.1177/0022002717708600.

16. Casar, M. A., \& Ugalde, L. C. (2019). Dinero bajo la mesa: Financiamiento y gasto ilegal de las campañas políticas en México. Grijalbo.

17. González-López, M. (2019). Understanding policy learning in regional innovation policies: lessons from the Galician case. Innovation: The European Journal of Social Science Research, 104-118. https://doi.org/10.1080/13511610.2018.1519780

18. Organization for Economic Co-Operation and Development (OECD). (2011). Regions and innovation policy, OECD Reviews of Regional Innovation. Paris: OECD Publishing. https://doi.org/10. 1787/9789264097803-en.

19. Trejo, G., \& Ley, S. (2016). Federalismo, drogas y violencia. Por qué el conflicto partidista intergubernamental estimuló la violencia del narcotráfico en México. Política y Gobierno, XXII(1), 11-56.

20. Vargas Rojas, K. H. (2016). The impact of Mexico-United States cooperation in the fight against money laundering. Revista Latinoamericana de Estudios de Seguridad(18), 61-74. https://doi.org/ 10.17141/urvio.18.2016.2229

21. México Evalúa. (2019). Hallazgos 2018. Seguimiento y evaluación del sistema de justicia penal en México. Ciudad de México: México Evalúa. Obtenido de https://www.mexicoevalua.org/hallazgos2018-seguimiento-evaluacion-del-sistema-justicia-penal-en-mexico/

22. Nieto, S. (2018). Sin filias, ni fobias. Memorias de un fiscal incómodo. Ciudad de México: Grijalbo.

23. Calderón, F. (2014). Los retosqueenfrentamos: Los problemas de México y laspolíticaspúblicas para resolverlos (2006-2012). . Ciudad de México: Debate.

24. Monsivais-Carrillo, A. (2019). Innovacióninstitucional para la rendición de cuentas: el Sistema NacionalAnticorrupción en México. Iconos - Revista de CienciasSociales, XXII, I(65), 51-69. https://doi.org/10.17141/iconos.65.2019.3793. 
25. Gamboa, C. (2012). Extinción de dominio. Estudio Teórico Conceptual, Marco Legal e Iniciativas presentadas en la LXI Legislatura. Ciudad de México: Cámara de Diputados. Obtenido de http:// www.diputados.gob.mx/sedia/sia/spi/SAPI-ISS-59-12.pdf

26. Heinle, K., Rodríguez, O., \& Shirk, D. (2017). Drug Violence in Mexico. Data and analysis through 2016. University of San Diego. San Diego, California: Justice in Mexico. Obtenido de https://justi ceinmexico.org/wp-content/uploads/2017/03/2017_DrugViolenceinMexico.pdf

27. Correa-Cabrera, G. (2018). Mexican security diagnosis and proposal to eradicate violence. Washington, D.C.: Wilson Center. Obtenido de https://www.wilsoncenter.org/sites/default/files/media/ documents/publication/mexican_security_diagnosis_and_a_proposal_to_eradicate_violence.pdf

28. Basu, G. (2014). The Strategic Attributes of Transnational Smuggling: Logistics flexibility and operational stealth in the facilitation of illicit trade. Journal of Transportation Security, 7(2), 99-113. https://doi.org/10.1007/s12198-013-0132-0.

29. Unger, B. (2013). Can Money Laundering Decrease? Public Finance Review, 41(5), 658-676. https://doi.org/10.1177/1091142113483353.

30. Garzón, J. C. (2013). Las "victorias" parciales y laspolíticas de "Mano dura" comofactores de empuje. In J. C. Garzón \& E. L. Olson (Eds.), La diáspora criminal: La difusión trasnacional del crimen organizado y cómo contener su expansión (págs. (pp. 1-26). Washington, D.C.: Wilson Center.

31. Valdés Castellanos, G. (2013). HistoriadelCrimenOrganizado en México. Ciudad de México: Aguilar.

32. Romero, V. (2020). Bloody investment: Misaligned incentives, money laundering and violence. Trends in Organized Crime. https://doi.org/10.1007/s12117-020-09391-x.

33. Dorantes, M., Flores Aza, D., \& Juarez, M. (2013). Región Noreste. Trabajo Final de Investigación y Análisis Económico. Obtenido de http://www.economia.unam.mx/cedrus/descargas/Noreste.pdf

34. FATF \& GAFILAT. (2018). Medidas anti lavado y contra la financiación del terrorismo México. Informe de Evaluación Mutua. FATF - GAFILAT, Paris. Obtenido de https://www.fatf-gafi.org/ media/fatf/documents/reports/mer4/IEM-Mexico-2018-Spanish.pdf

35. INEGI. (2019). INEGI. Recuperado el 13 de Octubre de 2020, de https://inegi.org.mx/app/areas geograficas $/$ ag $=08$

36. INEGI. (2020). Indicador Trimestral de la Actividad Económica Estatal. Recuperado el 13 de 10 de 2020, de https://www.inegi.org.mx/temas/itaee/default.html\#Informacion_general

37. CONEVAL. (2020). Pobreza en México. Mexico City: CONEVAL. Obtenido de https://www.conev al.org.mx/Medicion/Paginas/PobrezaInicio.aspx

38. SESNSP. (20 de Marzo de 2020). Secretariado Ejecutivo del Sistema Nacional de Seguridad Pública. Obtenido de Delitos del Fuero Común: https://www.gob.mx/sesnsp/acciones-y-programas/ incidencia-delictiva-del-fuero-comun-nueva-metodologia?state=published

39. Levi, M., \& Soudijn, M. (2020). Understanding the laundering of organized crime money. Crime and Justice, 49, 579-631. https://doi.org/10.1086/708047.

40. Bell, R. E. (1999). Civil forfeiture of criminal assets. The Journal of Criminal Law, 63(4), 371-384. https://doi.org/10.1177/002201839906300407.

41. Kelly, B. D., \& Kole, M. (2016). The Effects of Asset Forfeiture on Policing: A panel approach. Economic Inquiry, 54(1), 558-575. https://doi.org/10.1111/ecin.12232.

42. Gabbidon, S. L., Higgins, G. E., Martin, F., Nelson, M., \& Brown, J. (2011). An exploratory analysis of federal litigation in the United States challenging asset forfeiture. Criminal Justice Policy Review, 22(1), 50-64. https://doi.org/10.1177/0887403410365895.

43. Mughan, S., Li, D., \& Nicholson-Crotty, S. (2020). When law enforcement pays: Costs and benefits for elected versus appointed administrators engaged in asset forfeiture. The American Review of Public Administration, 50(3), 297-314. https://doi.org/10.1177/0275074019891993.

44. SCJN. (2019). Tesis I.15o.C.30 (10a). Gaceta del Semanario Judicial de la Federaci'n, IV(69), 4376. Obtenido de https://sjf.scjn.gob.mx/sjfsist/Paginas/DetalleGeneralV2.aspx?ID=2020353\& Clase $=$ DetalleTesisBL $\&$ Semanario $=0$

45. Miceli, T. J., \& Johnson, D. (2016). Asset forfeiture as a law enforcement tool. Contemporary Economic Policy, 34(1), 119-126. https://doi.org/10.1111/coep.12106.

46. Pimentel, D. (2017). Civil Asset forfeiture abuses: Can state legislation solve the problem? George Mason Law Review, 25(1), 173-219.

47. Boucht, J. (2014). Civil Asset Forfeiture and the Presumption of Innocence under Article 6(2) Echr. New Journal of European Criminal Law, 5(2), 221-255. https://doi.org/10.1177/203228441400500 206. 
48. Campbell, L. (2007). Theorising asset forfeiture in Ireland. The Journal of Criminal Law, 71(5), 441-460. https://doi.org/10.1350/jcla.2007.71.5.441.

49. Lukito, A. S. (2019). Revealing the unexplained wealth in Indonesian corporation: A revolutionary pattern in non-conviction- based asset forfeiture. Journal of Financial Crime, 27(1), 29-42. https:// doi.org/10.1108/JFC-11-2018-0116.

50. Calderón, F. (2009). Mensaje a la NacióndelPresidenteCalderón en materia de seguridad en el marco de sutercerinforme de gobierno. . Ciudad de México: Presidencia de la República.

51. Calderón, F. (2008). Discurso: El presidenteCalderón Hinojosa en la firma del decreto de la ReformaConstitucional en materia de Justicia Penal y SeguridadPública. Ciudad de México: Presidencia de la República.

52. Ruiz Cabello, M. D. (2011). Extinción de dominio, herramienta del derecho civil ante la ineficacia del derecho penal. Alegatos(77), 79-110. Obtenido de http://alegatos.azc.uam.mx/index.php/ra/artic le/view/301

53. SCJN. (2018). Tesis I.12o.C.46 C (10a). Gaceta del Semanario Judicial de la Federación, 2807. Obtenido de https://sjf.scjn.gob.mx/sjfsist/paginas/DetalleGeneralV2.aspx ?ID=2017541\&Clase $=$ DetalleTesisBL\&Semanario $=0$

54. Cuero Solís, J. F. (2017). The seizure of third-party assets in Spain and Colombia. Doctrina, 131160.https://doi.org/10.22518/20271743.810

55. SCJN. (2011). Tesis I.3o.C.884 C. Semanario Judicial de la Federación y su Gaceta(XXXIII), 2326. Obtenido de https://sjf.scjn.gob.mx/sjfsist/paginas/DetalleGeneralV2.aspx?ID=162831\&Clase= DetalleTesisBL\&Semanario $=0$

56. SCJN. (2011). Tesis I.3o.C.891 C. Semanario Judicial de la Federación y su Gaceta(XXXIII), 2316. Obtenido de https://sjf.scjn.gob.mx/sjfsist/Paginas/DetalleGeneralV2.aspx?Epoca=1e3e1 $0000000000 \&$ Apendice $=1000000000000 \&$ Expresion $=$. C. $891 \% 2520 \&$ Dominio $=$ Rubro, Texto $\&$ TA_TJ $=2 \&$ Orden $=1 \&$ Clase $=$ DetalleTesisBL\&NumTE $=1 \& E p p=20 \&$ Desde $=-100 \&$ Hasta $=-100 \&$ Index $=0 \&$ InstanciasSeleccionadas $=$

57. SCJN. (2015). Tesis 1a./J. 20/2015 (10a.). Gaceta del Semanario Judicial de la Federación(17), 330. Obtenido de https://sjf.scjn.gob.mx/SJFSist/paginas/DetalleGeneralV2.aspx?Clase=DetalleTes isBL\&ID $=2008873 \&$ Semanario $=0$

58. Goldsmith, M., \& Linderman, M. J. (1989). Asset Forfeiture and Third Party Rights. Duke Law Journal, 1989(5), 1254-1301. Obtenido de https://papers.ssrn.com/sol3/papers.cfm?abstract_id= 884466

59. Chi, K. A. -Y. (2002). Follow the money: Getting to the root of the problem with civil asset forfeiture in California. California Law Review, 90(5), 1635-1673. https://doi.org/10.2307/3481366.

60. Clingermayer, J. C., Hecker, J., \& Madsen, S. (2005). Asset forfeiture and police priorities: The impact of program design on law enforcement activities. Criminal Justice Policy Review, 16(3), 319-335. https://doi.org/10.1177/0887403404271482.

61. Lasky, M. R. (2014). Imposing indigence: Reclaiming the qualified right to counsel of choice in criminal asset forfeiture cases. The Journal of Criminal Law \& Criminology, 104(1), 165-194.

62. Simon, J. (2017). Civil Asset Forfeiture in Virginia: An Imperfect System. Washington and Lee Law Review, 74(2), 1296-1341. Obtenido de https://scholarlycommons.law.wlu.edu/cgi/viewcontent.cgi? article $=4564 \&$ context $=$ wlulr

63. Londen, P. (2015). Arizona's Civil Asset Forfeiture Scheme: Distorted Justice. Arizona State Law Review, 475-507. Obtenido de https://arizonastatelawjournal.org/2015/08/06/arizonas-civil-assetforfeiture-scheme-distorted-justice/

64. Moreno Hernández, M. (2011). Lavado de dinero. (págs. 45-70). Ciudad de México: Cámara de Diputados. Retreived from: http://biblioteca.diputados.gob.mx/janium/bv/cedip/lxi/lavdin_serverd. pdf

65. González, J. d. (2018). Extinción de dominio. Propuestas legislativas y acciones de política pública. Ciudad de México: CESOP. Obtenido de http://www5.diputados.gob.mx/index.php/camara/Centr os-de-Estudio/CESOP/Estudios-e-Investigaciones/Documentos-de-Trabajo/Num.-296.-Extincionde-Dominio.-Propuestas-legislativas-y-acciones-de-politica-publica

66. Gobierno de Chihuahua. (2016). Sexto Informe de Gobierno. Chihuahua 2010-2016. Chihuahua: Gobierno de Chihuahua. Obtenido de http://www.chihuahua.gob.mx/informes-de-gobierno/docs/ 2016/informe_de_gobierno_2016.pdf

67. Gobierno de Sonora. (2019). Cuarto Informe de Gobierno. Hermosillo: Gobierno de Sonora. Obtenido de https://informe.sonora.gob.mx/images/documentos/2019/4to-informe-de-trabajo.pdf

68. Torres Estrada, P. R. (2019). Los razonamientos Jurídicos de la Política pública. Tirant Lo Blanch. 
69. Arnone, M., \& Borlini, L. (2010). International anti-money laundering programs: Empirical assessment and issues in criminal regulation. Journal of Money Laundering Control, 13(3), 226-271. https://doi.org/10.1108/13685201011057136.

70. SESNSP. (31 de Marzo de 2020). Secretariado Ejecutivo del Sistema Nacional de Seguridad Pública. Obtenido de Secretariado Ejecutivo del Sistema Nacional de Seguridad Pública: http:// secretariadoejecutivo.gob.mx/docs/pdfs/normateca/Reglamentos/FortalecimientodelasUnidades.pdf

71. Organization of American States (OAS). (1991). Model Regulations on Money Laudering Offenses Related to Drug. Obtenido de http://www.cicad.oas.org/lavado_activos/eng/Model_regula_eng12_ 02/REGLAMENTO\%20LAVADO\%20-\%20ENG.pdf

72. Ojeda Bohórquez, R. (2010). Análisis Jurídico en Materia de Narcomenudeo. Revista del Instituto Judicatura Federal(30), 245-255. Obtenido de https://revistas-colaboracion.juridicas.unam.mx/ index.php/judicatura/article/view/31958/28949

Publisher's Note Springer Nature remains neutral with regard to jurisdictional claims in published maps and institutional affiliations. 